\title{
STAVEBNÍ VÝVOJ KAMENNÉ ČTVRTI V BRNĚ
}

\section{CONSTRUCTION DEVELOPMENT OF KAMENNÁ ČTVRŤ IN BRNO}

\author{
Sofie Pokorná*,1
}

sofie.pokorna@usi.vutbr.cz

'Ústav soudního inženýrství VUT v Brně, Purkyňova 118, Brno Abstrakt

Článek se zabývá vývojem stavby v bývalé dělnické kolonii Kamenná čtvrt’ v Brně. Vysvětluje pojem gentrifikace, přibližuje Kamennou čtvrt’ a její historii. Rozebírá počáteční výstavbu a její proměnu v průběhu let až po současnost. V závěru diskutuje nad možností vývoje výstavby v takovéto lokalitě, přičemž si nedává za cíl navrhnout přímé řešení ale poukázat na možné směrování vývoje. Použitými metodami byly výzkum historie, kvalitativní sociologický průzkum použitím výzkumné techniky vedení rozhovorů a dotazníkového šetření.

\section{Klíčová slova}

Kamenná čtvrt', dělnická kolonie, gentrifikace, vývoj stavby, Brno.

\begin{abstract}
The article describes the development of the construction in former workers' colony Kamenná čtvrt' in Brno. It explains the concept of gentrification, describes Kamenná čtvrt' and its history. It analyzes the initial construction and its transformation over the years to the present. In the end, it discusses the possibility of development of construction in this type of locality, while it does not aim to propose direct solution but to point out possible direction of development. The methods used were history research, qualitative sociological research using the interview technique and questionnaire survey.
\end{abstract}

\section{Key words}

Kamenná čtvrt', workers' colony, gentrification, construction development, Brno.

\section{1 ÚVOD}

Kamenná čtvrt’ v Brně je nejznámější brněnskou dělnickou kolonií. V průběhu své historie dostala punc umělecké čtvrti, což ji zůstalo dodnes.

Dělnické čtvrti a další deprivované městské lokality všude po světě zažívají sociologicko-ekonomicko-kulturní transformaci, které se nazývá gentrifikace. Jedná se o proměnu chudé čtvrti v lokalitu úspěšnou, žádanou a drahou. To vše se děje v průběhu let a kromě proměny obyvatel, kultury či hodnoty tamních nemovitostí a nájmů lze sledovat transformaci lokality i z pohledu stavařského a architektonického [3]. Jelikož je pro pochopení problematiky lepší uvádět př́iklady, byla pro tento záměr vybrána gentrifikovaná bývalá dělnická kolonie Kamenná čtvrt'.

Gentrifikace je jev hojně diskutovaný v západních zemích, kde tržní ekonomika přišla dřive než v zemích postsocialistických. Kromě pozitiv, jako jsou snížení kriminality v lokalitě či její renovace, s sebou totiž nese i negativa. Těmto negativním vlivưm by se možná dalo předcházet, a to by mělo být pro vědce, politiky i veřejnost motivací o gentrifikaci zjistit maximum.

Tento článek si bere za cíl uvést lajka do problematiky gentrifikace, představit Kamennou čtvrt', zmapovat a popsat způsoby výstavby v průběhu historie a podívat se na transformaci architektury v této lokalitě. 


\section{POPIS SOUČASNÉHO STAVU}

\section{Gentrifikace}

V roce 1964 bylo poprvé použito slovo gentrifikace ve studii anglické vědkyně Ruth Glass o sociální proměně původně industriální čtvrti Londýna. Studie zachycovala stěhování nižší šlechty z venkova a periferií Londýna do centrální části města a postupné, ale kompletní vyloučení původního dělnického obyvatelstva [1].

Gentrifikaci lze zjednodušeně chápat jako revitalizaci zchátralého obytného prostředí centrálních částí velkých měst, kdy je zároveň původní dělnické obyvatelstvo nahrazováno střední či vyšší společenskou třídou. $\mathrm{K}$ tomuto procesu dochází v oblastech se zastaralým a poničeným bytovým fondem, které jsou ale z nějakého důvodu atraktivní. Atraktivita takové lokalita může být v poloze blízko centra města, specifičnosti lokality nebo třeba v historickém či architektonickém pozadí [4].

Úplné vyloučení dělnické třídy nastává postupně v průběhu desetiletí především ekonomickým nátlakem, který je způsobován postupnou obměnou obyvatel. S nově prŕíchozí společenskou třídou do lokality postupně přicházejí i dražší obchody a služby. Večtvrti se pořádá více kulturních akcí, o lokalitě se píše a mluví a v návaznosti na to se do této oblasti stěhuje více lidí ze střední či vyšší společenské vrstvy. Zároveň pod tímto vlivem je město ochotné do gentrifikované čtvrti investovat. To přitahuje i soukromé investory, kteří získávají finanční jistotu [2].

Genrtifikace má nesporné klady, jako je snižování kriminality, revitalizace lokality či bohatší kulturní život. Je však důležité si uvědomit, že každá změna, která na počátku vyznívá pozitivně, se může zvrhnout v negativum. Názorným př́íkladem může být renovace starých budov, která může vést až ke ztrátě autentičnosti dané lokality. Nebo také sociální zpestření obyvatel ve čtvrti. Někteří sociologové se domnívají, že tato sociální heterogenita je pouze dočasná nebo že v lokalitě vzniká nová společenská hierarchie. V této hierarchii jsou původní obyvatelé přesunuti na spodní přičky, cítí se vykořistěni a dobré vztahy mezi gentrifikanty a starousedlíky jsou zpřetrhány [5], [6].

\section{Kamenná čtvrt’}

V období První republiky přišel obrovský technologický rozvoj. Vznikaly nové továrny a staré se rozšiřovaly a modernizovaly. V těchto továrnách vznikala pracovní místa, za nimiž se do velkých měst stěhovali lidé z venkova. Na to ale město Brno nebylo připraveno, a tak tento př́liv nových obyvatel způsobil bytovou krizi. Nový obyvatelé Brna často bydleli na místech se značně nevyhovujícími hygienickými podmínkami, na malých prostorech a s každodenním úsilím se vyhnout obvinění z potulky [7].

Toto období jednoznačně přálo vzniku tzv. dělnických či nouzových kolonií. Těch po Brně vzniklo ve 20. a 30. letech 20. století cca 20 [4]. Kamenná kolonie (dnes Kamenná čtvrt') patřila spolu s Divišovou čtvrtí $\mathrm{k}$ těm největším, a dnes obě patří k těm zachovalejším.

\section{Umístění a morfologie}

Kamenná čtvrt' spadá pod městskou část Brno - Střed, přičemž je součástí katastrálního území Štýřice a nachází se jihozápadně od centra města. Leží na pravém břehu řeky Svratky asi $1 \mathrm{~km}$ od tramvajové zastávky Poříčí. Ze severní strany Kamennou čtvrt' obtéká řeka Svratka. Ze západní strany Kamennou čtvrt' obklopuje městská louka. Ze strany jižní leží Červený kopec a ze strany východní přes malý lesík dále navazuje zástavba vedoucí k ulici Vídeňská.

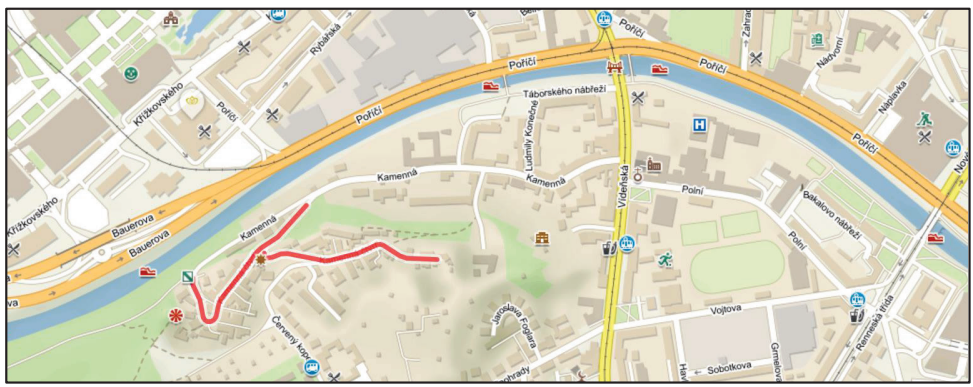

Obr. 1 Umístění Kamenné čtvrti ve městě Brně [14]. 
Z pohledu geologického se Kamenná čtvrt’ nachází na kopci ve dvou bývalých kamenolomech s přirozeným horninovým podkladem tvořeným pískovci a slepenci devonského stáří a jejich zvětralinami. Celá oblast byla však ovlivňována těžbou kamene, a tak je původní mocnost hornin navýšena množstvím odvalů navážek z bývalých lomů. Místy se jedná o mocnost těchto navážek a odvalů až $10 \mathrm{~m}$ [9].

\section{Stručná historie}

První dům byl postaven ve spodním lomu v roce 1925, od roku 1928 se stavělo i v horním lomu a výstavba celé kolonie byla dokončena na sklonku 30. let. Původní obyvatelé byli převážně zaměstnáni v nedalekých Kohnových cihelnách. Výstavba vzniká na etapy, které jsou dlouhé sedm měsíců až tři roky. Obyvatelé museli zaplatit tzv. "roční uznatelné", což byl poplatek za užívání obecního pozemku vždy do určitého roku a s možností odvolání i bez udání důvodů. V roce 1927 byla v kolonii vybudována první vodovodní pumpa [10], [11].

V letech 1928 až 1932 byla vystavěna nejvýchodnější a nejvýše položená část čtvrti na městských pozemcích. Přilehlý soukromý pozemek skýtal stále ještě otevřený lom. Domy byly stavěny, jako provizorní se stavebním povolením i bez něj, to však bylo vydáváno dodatečně. Stavbám byla úřady vytyčena lhůta pro odstranění, to ale bylo realizováno jen výjimečně [12].

Ve 30. letech byla ve spodní části Kamenné čtvrti zavedena kanalizace. V tomto období soukromý pozemek v horní části přešel na jiného majitele, který zde povolil další výstavbu. Zároveň však město usilovalo o zrušení kolonie, proti kterému se vymezili komunisté [12].

Ve 40. letech byla v horní části čtvrti zavedena elektřina, byly zrušeny místní veřejné záchody, zaveden jednotný svoz odpadů a otevřen obchod s potravinami ve spodní části. V tomto období bylo evidováno 132 nouzových domků v Kamenné kolonii [12].

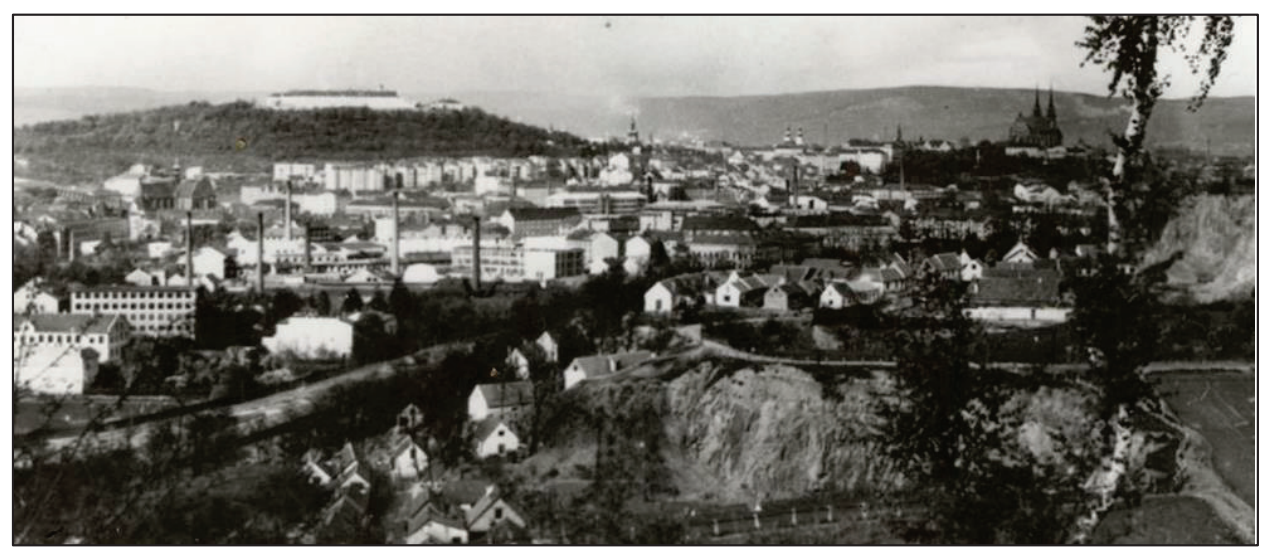

Obr. 2 Pohled na Kamennou kolonii počátkem 40. let [11].

V 50. letech byla vybudována provizorní vodovodní sít'. Byla provedena plynofikace v obou částech a Kamenná kolonie je oficiálně v roce 1958 přejmenována na Kamennou čtvrt'. Také byl vybudován kulturní dům a úřady se stále snažily najít cestu, jak kolonii zrušit [12].

V 60. letech bylo dokonce vydáno nařízení o likvidaci několika domků, likvidace ale nebyla uskutečněna [11].

V 70. letech bylo asi $80 \%$ původního obyvatelstva dobrovolně přestěhováno na nově vystavěná brněnská sídliště, jelikož svůj původ vnímali jako stigma. V roce 1974 byla Kamenná kolonie jmenována dělnickou revoluční památkou a uvažovalo se o její přeměně na muzeum dělnického hnutí, které by ukazovalo špatné životní podmínky dělníku za kapitalistické první republiky. V těchto letech je v Kamenné čtvrti evidováno 128 domů na 260 obyvatel starších 18 let. O lokalitu projevilo zájem BVV, které chtělo na místě zbudovat sklady a pohostinství pro interní potřeby a vystavět předváděcí vzorové domy. Ve hře bylo i zbudování skanzenu, v němž by mohli dožívat přestárlí převážně místní občané se stálou pečovatelskou službou. K realizaci těchto návrhů nedošlo díky nedostatku náhradních bytů pro místní obyvatele. V roce 1979 byl dokonce vytvořen brněnským VUT projekt skanzenu s expozicí uměleckých řemesel a tradic a moderních ubytoven pro studenty a pro potřeby BVV [11], [13]. 
V 70. a 80. letech byly nemovitosti od původních obyvatel za nízké ceny odkoupeny tzv. průkopníkům (první "odvážlivci" stěhující se do deprivované lokality) z řad mladých umělců, řemeslníků, učitelů atd. [13]. Po roce 1989 se o Kamenné kolonii hovořilo, jako o umělecké čtvrti a začaly se sem stěhovat první gentrifikanti z vyšších společenských vrstev. V tomto období začaly i prudce stoupat hodnoty nemovitostí.

Tab. 1 Srovnání nárůstu cen pozemků (dle cenových map) vybraných bývalých dělnických kolonií v Brně.

\begin{tabular}{|c|c|c|c|c|}
\hline Platnost cenových map & Kamenná čtvrt' & Divišova čtvrt' & Písečník & Myslínova \\
\hline 1. 4. $2006-31.12 .2009$ & $630,-\mathrm{Kc \check {c } / \mathrm { m } ^ { 2 }}$ & $1060,-\mathrm{Kc} \check{c} / \mathrm{m}^{2}$ & $800,-\mathrm{Kč} / \mathrm{m}^{2}$ & $610,-\mathrm{Kc \check {c }} / \mathrm{m}^{2}$ \\
\hline 1. $1.2010-31.12 .2011$ & 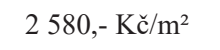 & $2250,-\mathrm{Kc \check {c }} / \mathrm{m}^{2}$ & $1550,-\mathrm{Kc \check {c }} / \mathrm{m}^{2}$ & $2500,-\mathrm{Kc} / \mathrm{m}^{2}$ \\
\hline 1. 1. $2014-31.8 .2017$ & $2580,-\mathrm{Kč} / \mathrm{m}^{2}$ & $2390,-\mathrm{Kč} / \mathrm{m}^{2}$ & $1550,-\mathrm{Kč} / \mathrm{m}^{2}$ & $2500,-\mathrm{Kč} / \mathrm{m}^{2}$ \\
\hline
\end{tabular}

\section{METODIKA}

Tato práce je mezioborovou a spojuje technické a sociální vědy. Snaží se nalézt odpovědi v historii a propojit technickou a urbanistickou stránku lokality se stránkou sociální. Sociální tlak má následně vliv na další utváření urbanismu a architektury $\mathrm{v}$ dané čtvrti.

V první části tohoto článku je využito průzkumu historie a ve druhé části je vycházeno ze sociologického průzkumu vedeného formou dotazníkového šetření a rozhovorů s místními obyvateli. Dotazníkové šetření mělo 59 respondentů, což odpovídá $1 / 3$ domů a proběhlo v roce 2019. Jeho výsledky jsou podrobně prezentovány ve zdroji č. 7. Rozhovory jsou vedeny s 9 lidmi v průběhu let 2018-2021 ve stylu tzv. reflexivního interview.

\section{VÝSTAVBA KAMENNÉ KOLONIE OD POČÁTKŮ AŽ PO SOUČASNOST}

Na počátku výstavby byly domy stavěny tzv. "na kostru". Jednalo se o výstavbu dřevěného rámu, který byl následně vyplněn zdivem. Zdivo bylo ve velké míře používáno z bouraček jiných domů z celého Brna [11]. Tento fakt je vidět v současnosti při každé rekonstrukci místních domků, kde jsou k nalezení cihly z různých brněnských cihelen. Dále se používaly zmetkové cihly z nedalekého smetiště cihelny Kohn a Jílek. V tomto období byly domy stavěny v nejnutnějším vzorci kuchyn̆ + pokoj. Domy v počátcích neměly vlastní hygienické místnosti a ve spodní části Kamenné čtvrti byly vybudovány veřejné záchody. Ve 30. letech byla do spodní části zavedena kanalizace a až do 80. let bylo běžné umístění splachovacího záchodu na dvorku [11]. Prostor mezi jednotlivými domy byl dostačující pro malé hospodářství, i když o ulici se dá hovořit pouze jako o "páteřní linii" v horní a ve spodní části. Z této linie dále vybíhaly uličky některé pouze pro pěší dostupnost, avšak v této době bylo uliček v porovnání se současností více a prostor mezi jednotlivými domky kromě uliček vymezovaly i zahrádky a dvorky.

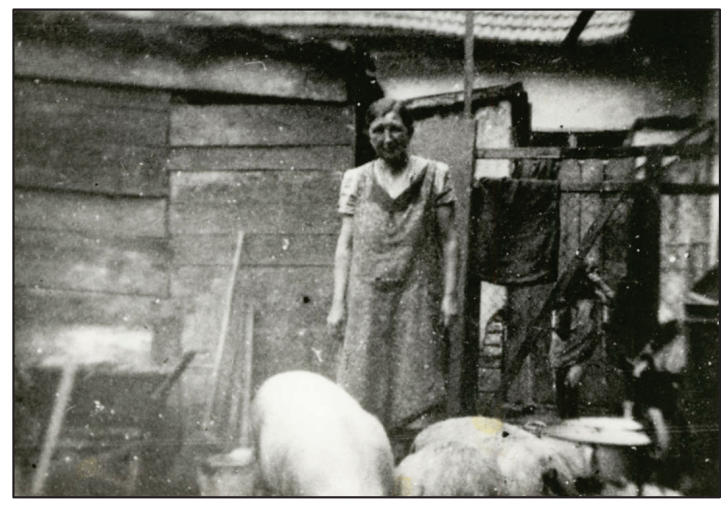

Obr. 3 Předválečná fotografie dokumentující chov vepřo̊ v Kamenné kolonii [11]. 
V pozdějších letech byly velkými kroky k rozvoji čtvrti zavedení elektřiny, svozu odpadů, plynofikace či tzv. zbudování provizorního vodovodu, který funguje dodnes a jeho rekonstrukce byla již několikrát odložena. S rozvojem ekonomiky a s ním spjatým zlepšování životní úrovně se místní zasazovali o budování většího prostoru k životu v podobě přístavků a nástaveb ze dřeva, cihel či kotovic.

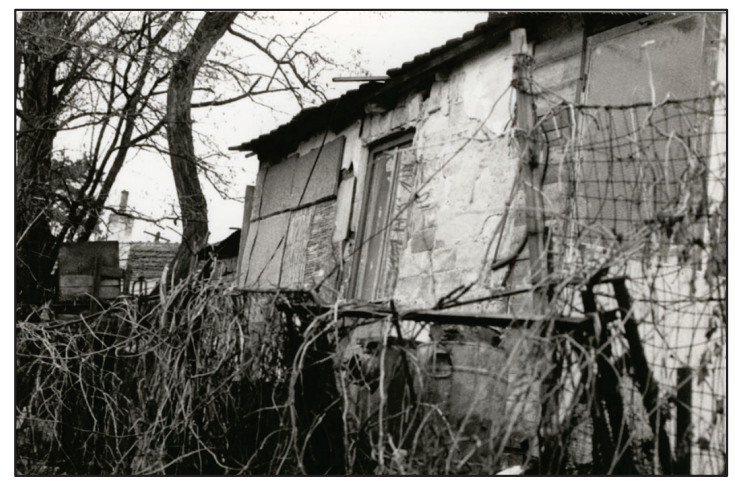

Obr. 4 Obytný přístavek, foceno v 70. letech [11].

V 70. a 80. letech se Kamenná čtvrt' s př́íchodem obyvatel řemeslných a uměleckých profesí začala měnit. Jednalo se o průkopníky (v odborných textech se běžně užívá i anglický výraz 'pioneer'), jejichž příchod je typický pro první fázi gentrifikace. Tito noví obyvatelé koupili domy za velmi nízké ceny, ale ve zchátralém stavu a často ještě v základním vzorci pokoj + kuchyně. Jejich devizou jednoznačně byla tvořivost, nápady, um a časový prostor pro rekonstrukci vlastních obydlí i blízkého okolí. Stavby v Kamenné čtvrti byly rožsiřovány o koupelny, obývací pokoje a další ložnice. Byly zastavovány některé úzké uličky mezi domy, částečně i dvorky či zahrádky a zbylé dvorky byly oploceny vyššími ploty. To vše se často dělo bez svolení úřadů i bez jejich dodatečného souhlasu. Na fasádách i v interiérech byly užívány umělecké prvky v podobě soch či maleb a okna začaly zdobit vitráže. Vitráže byly v hojné míře užívány v oknech směrem do uliček, a kromě estetického efektu, zajišt'ovaly obyvatelům větší míru soukromí. Tento trend se v Kamenné čtvrti drží dodnes, a to i u některých nově zrekonstruovaných domů.

V 90. letech se pověst Kamenné čtvrti pomalu začala měnit, z chudinské kolonie bez kanalizace (ta v horní části chybí i dnes) se pomalu začala stávat bohémská umělecká čtvrt'. Společenské vnímání lokality přitáhlo první gentrifikanty ze střední třídy, kteří ale měli podobnou touhu po komunitním životě a vkus jako průkopníci. Domy se dále rekonstruovaly a proměňovaly. Z nekvalitních př́stavků slepených z různých materiálů se začaly stávat regulérní př́istavby a u mnoha staveb proběhly kompletní rekonstrukce.

Po přelomu tisíciletí a větším rozmachem gentrifikace se v dané čtvrti rozmohl trend koupit dva sousedící domy a propojit je v jeden větší. Zde se ale nabízí otázka, jestli se zvyšováním standardu bydlení by bylo reálné obývat prostor o velikosti původních domků se 4člennou rodinou. Jestliže ne, neměl by se opravdu stát skanzen z každé bývalé dělnické kolonie? Tudy cesta patrně nevede.

V roce 2010 byla páteřní ulice v horní i dolní Kamenné čtvrti a spojovací ulice mezi čtvrtí a ulicí Kamenná vyasfaltována.
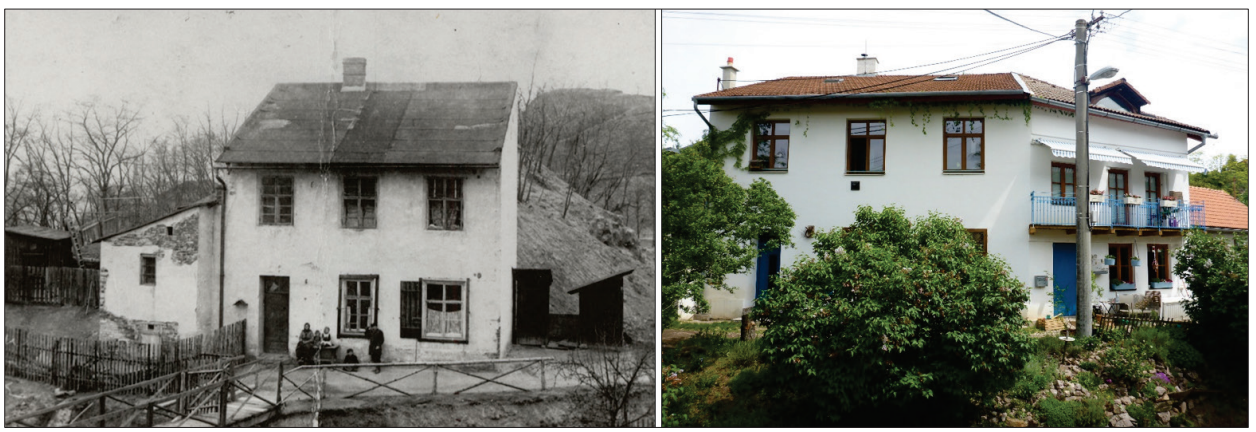

Obr. 5 Nejstarší dům v Kamenné kolonii těsně před počátkem výstavby nouzových domků (vlevo) a jeho dnešní podoba [11]. 


\section{ZÁVĚR}

Ve vyprávění pamětníků i průkopníků není výjimkou zmínka o stigmatizujícím př́stupu k lidem z Kamenné čtvrti. Tito lidé nejčastěji zmiňují pohrdání bydlením v dělnické kolonii ze stran úřadů a pedagogů na základních školách svých dětí. Z tohoto pohledu je dnes již gentrifikovaná lokalita vnímána zcela opačně. Lokalita sklízí obdiv díky umístění v blízkosti centra i městského lesoparku a návštěvníci obdivují genius loci i komunitní život. Gentrifikace v tomto pohledu Kamenné čtvrti prospěla. Mají z toho však užitek původní obyvatelé? To patrně ne. Těch sveřepých zde zůstala jen hrstka, navíc dnes již vymírají a zlepšení pověsti spíše ani nevnímají. Za to průkopníků ve čtvrti žije stále dost a bez větších problémů vycházejí i s nově př́chozími. Ti zlepšení pověsti i zvyšování hodnoty jejich nemovitostí vnímají pozitivně, ale o obavách z velkých změn někteří také hovoří.

Jednoduché obydlí v minimalistickém pojetí, které vdechuje Kamenné čtvrti jedinečnost, se pomalu mění spojováním staveb v jednu větší ve zcela jiný typ nemovitostí. Výjimkou není ani navyšování domů, zmohutňování konstrukcí a modernizace jak po stránce vizuální, tak materiálové. To vše je v rámci vývoje společnosti a zvyšování standartu bydlení pochopitelné, avšak stojí za zamyšlením, jestli je to $\mathrm{v}$ pořádku v památkově chráněné lokalitě. Dalo by se $\mathrm{v}$ dnešní době žít $\mathrm{v}$ domech o původních rozměrech se 4členou rodinou? A jestliže ne, měla by tedy taková lokalita sloužit jen pro singles nebo bezdětné páry? Jako by se z variant zachování původního stavebního vzorce a nové "propojovací mánie" stala otázka, jestli je na místě myslet na Kamennou čtvrt' z pohledu budoucnosti, kterou děti ztělesňují nebo z pohledu historie, za niž stojí dělnická minulost, která je do urbanistického řešení a osobitosti čtvrti neotřele vtisknuta.

\section{Použité zdroje}

[1] GLASS, R. Centre for Urban Studies report, MacGibbon \& Kee. University College, London. Centre for Urban Studie, 1964. OCLC 1618199.

[2] SQUIRES, G. D. Form Redlining To Reinvestment. Philadelphia: Temple University Press, 1992. ISBN 978-1-4399-0165-6.

[3] POKORNÁ, S. GENTRIFIKACE. In: XIII. ROČNÍK ODBORNÉ KONFERECE DOKTORANDSKÉHO STUDIA. Brno: VUT v Brně, ÚSI, 2021, s. 137-146. ISBN 978-80-2145963-2.

[4] SLAVIČÍNSKÝ, J. KAMENNÁ KOLONIE A OBČANSKÉ SDRUŽENÍ KAMENKA: - případová studie -. Brno, 2006. Diplomová práce. MU v Brně.

[5] VIGDOR, Jacob L. Does Gentrification Harm the Poor? Brookings-Wharton Papers on Urban Affairs [online]. 2002, 2002(1), 133-182 [cit. 2020-11-14]. ISSN 1533-4449. Dostupné z: doi:10.1353/urb.2002.0012

[6] LEES, Loretta. Super-gentrification: The Case of Brooklyn Heights, New York City. Urban Studies [online]. 2003, 40(12), 2487-2509 [cit. 2021-5-14]. ISSN 0042-0980. Dostupné z: doi:10.1080/0042098032000136174

[7] POKORNÁ, S. Vliv specifické lokality na cenu rodinného domu: Brno - Kamenná kolonie. Brno, 2019. Diplomová práce. VUT v Brně, ÚSI.

[8] DŘíMAL, J. a V. PEŠA. Dějiny města Brna 2. Brno: Blok, 1973, I.(2), 378.

[9] KREJČÍ, O. Stanovisko k sesuvným územím v Brně. Dostupné z: kamenka.eu: ČESKÁ GEOLOGICKÁ SLUŽBA, 2004.

[10] ČEPELÁKOVÁ, J. Slovesné projevy v nouzové dělnické kolonii Kamenná čtvrt' v Brně. Brno, 1981. Diplomová práce. Katedra etnologie UJEP.

[11] BOCHOLÁ ̌̌, T. Způsob života dělnických rodin v brněnské Kamenné čtvrti. Brno 1979. Diplomová práce. Katedra etnologie UJEP.

[12] LAICHMAN, M. Brněnské nouzové kolonie za předmnichovské republiky, Vlastivědný věstník moravský XIV, 1959, s. 25-29.

[13] SVOBODOVÁ, J. Brněnské obytné kolonie, Brno v minulosti a dnes XV, 2001, s. 381-462.

[14] Mapy.cz. Mapy.cz [online]. [cit. 2018-10-09]. Dostupné z: https://mapy.cz/s/37p9k 